\title{
Violence in South African Schools: Perceptions of Communities about a Persistent Problem
}

\author{
Dr Miranda N. Mgijima \\ University of South Africa (UNISA), College of Education, \\ Department of Educational Leadership and Management \\ mgijimm@unisa.ac.za / nomsomgjm4@gmail.com
}

\section{Doi:10.5901/mjss.2014.v5n14p198}

\begin{abstract}
Multiple incidents of violence in South African schools have elevated the issue to being a national concern. The aim of this article is to report on an investigation into the perception of school communities regarding conditions that make violence such a persistent problem in schools. Located within the critical emancipatory research (CER) paradigm, the article emanates from a larger community engagement project, which is a sequel to a study on the dynamics of violence in schools conducted in 2011*. Qualitative data were collected in 2013 through a series of focus group discussions involving 698 participants in two provinces. Preliminary findings reveal that weak leadership, ineffective or dysfunctional governance and management structures, poor parental participation, lack of teacher professionalism and an overall lack of accountability militate against successful implementation of intervention strategies. It is then suggested that mobilising communities, empowering and equipping them with relevant knowledge and skills is likely stimulate appropriate action towards the reduction of violence in schools.
\end{abstract}

Keywords: violence; critical emancipatory research; duty of care; accountability

\section{Introduction}

Violence in South African schools is rampant and has been so for a while. As far back as 1999, Kader Asmal, the former Minister of Education, strongly condemned the unacceptably high levels of violence and directed that schools must be reclaimed as "spaces of peace and stability" (Department of Education, 2000). Yet, violent incidents continue making news headlines. Both learners and teachers are equally at risk, as victims but also as perpetrators of violence (de Wet, 2009; Mncube and Harber, 2012). School violence manifests itself in different forms. Learner-on-learner violence is common. Violence by teachers against learners and by learners against teachers is also common. Teacher-on-teacher violence happens although on a limited scale.

Backed by extensive legislation, several government interventions have been introduced over the past 13 years. The law places the duty of care to protect learners at school squarely on the shoulders of educators. It is the responsibility of the principal to ensure compliance with legislation and policies. Failure to do so implies lack of accountability, which means inability to give "an account to designated people about one's actions concerning mandated duties" (van der Westhuizen, 2003 in Naidu et al 2013:40). A principal must therefore be answerable that indeed the task of ensuring safety in schools as mandated by law is duly performed. Whilst the principal remains accountable for all school operations, the leadership and management functions are distributed among various structures as provided for in the South African Schools Act (Republic of South Africa, Act 84 of 1996). This makes prevention of school violence a collective responsibility among school governing bodies (SGBs); school management teams (SMTs) and learner representative councils (LRCs).

Whilst research has been conducted widely on the problem of school violence in terms of its causes and consequences (Mncube and Harber, 2012), very few studies relate violence to the ethics of care (de Wet, 2007; Grant, Jasson and Lawrence, 2010). This study seeks to contribute towards closing this gap. The research is exploratory, seeking to advance the understanding of the pervasiveness of the problem of violence in schools despite the legislation that is in place. This article emanates from a larger community engagement study that is conducted in two of South Africa's nine provinces.

\section{School Violence and the Legislative Context}

In South Africa, the right to learn in a safe and secure environment is protected by law. The Bill of Rights, in the 
Constitution guarantees every citizen the right to human dignity, equality, freedom and security. Section 12 states that everyone has the right not to be treated or punished in a cruel, inhuman or degrading way (Republic of South Africa, Act No. 108 of 1996). The National Education Policy Act (Act 27 of 1996) stipulates that no person shall administer corporal punishment or subject a student to psychological or physical abuse at any educational institution. In terms of Section 16(3) of the South African Schools Act (SASA), the principal has a primary responsibility to ensure that learners are not subjected to crimen injuria, assault, harassment, maltreatment, degradation, humiliation or intimidation from educators or other learners. Educators "have a 'duty of care' and must protect learners from violence because of their in loco parentis status" (Act 84 of 1996: 70).

The Regulations to Prohibit Initiation Practices in Schools (Government Gazette 24165, 2002:68) define "in loco parentis as acting in the place of a parent who has entrusted the custody and control of his or her child to an educator or another person during normal intramural or extramural school activities". These Regulations stress that appropriate measures must be taken to protect the learner from all forms of physical or mental violence, including sexual abuse, while in the care of any person who acts in loco parentis.

The Norms and Standards for Educators (Government Gazette 20844, 2000: 48) list "Community, citizenship and pastoral care" as one of the seven roles of educators, in terms of which they must demonstrate a caring, ethical attitude, respect and professional behaviour towards including learners. Similarly, the Employment of Educators Act (76 of 1998) prescribes that teachers should exercise self-discipline, and refrain from improper physical contact with learners and any educator must be dismissed if found guilty of committing an act of sexual assault on a learner, student or other employee and for having a sexual relationship with a learner of the school where he or she is employed. The Regulations for Safety Measures at Public Schools (Government Gazette 22754, 2001: 66), mandate principals "to take all steps necessary to safeguard the public school premises, as well as to protect people therein". Despite these laws and regulations, the problem has persisted unabated, inviting a closer look in order to understand how violence manifests itself within schools.

\section{Manifestation of Violence in Schools}

The external environment has a major influence on school violence. Schools are regarded as the microcosm of society (Adams 1993; Gottfredson and Gottfredson 1985; McDermont 1983 cited in Adams, 2000). However, for the purposes of this article, focus is on how violence is manifest inside schools. A study by Mncube and Harber (2012) found as commonplace incidents such as bullying, taunting, ridicule, belittling, intimidation, abusive and derogatory language. Sexual, ethnical and racial harassment are also rife. According to Liang, Flisher and Lombard (2007) bullying behaviours are the most common, and male students are most at risk of both perpetration and victimisation, while younger boys were more vulnerable to victimisation. Acts of physical violence include vandalism, assaults, shootings, gang rape, stabbings and corporal punishment (Mncube and Harber, 2012). Relational aggressive behaviour, reduced deference to authority, and disruptive classroom behaviour are also common (Akiba, LeTendre, Baker and Goesling (2002); Prinsloo (2006); Zulu, Urbani and Van der Merwe (2004) in Mncube and Harber, 2012).

Mncube and Harber (2012) posit that sexual harassment of female learners by males in is prevalent in many schools. The same was reported by Prinsloo (2006: 305), pointing that "shocking reports in the newspapers from 1999 to 2004 have indicated that sexual harassment of female learners is a problem in many of our schools." As a result, some girls fall pregnant, contract sexual diseases, become stressed, develop poor self-esteem or become emotionally withdrawn. For others, it leads to absenteeism or it contributes to low achievement causing girls to eventually drop out of school. Mncube and Harber (2012:71) analysed "teacher verbal violence" and found that use of "vulgar language", or calling students "nasty words" is common. Teachers also violate learners through unsolicited physical contact such as groping or fondling, coercive sex and even rape. A study by Hyman and Perone (1998), revealed that victimisation of students by teachers often in the name of discipline was quite prevalent.

The South African media in 2012 reported a learner attacking an educator with a broom and with a chair. Another teacher was beaten unconscious after confiscating cellular phones during examinations. A learner fatally stabbed a fellow learner at school in KwaZulu-Natal in 2013. In 2012, a principal assaulted an educator in New Castle in full view of learners and other teachers. In Mpumalanga, a teacher applied corporal punishment causing a learner to be paralysed. Five years ago, a learner in Gauteng hacked another learner to death with a samurai sword and injured three others.

Contrary to the general perception that school violence is often caused by learners who are ill-disciplined and whose behaviours are anti-social, the above evidence suggests that both learners and educators are victims and perpetuators of violence. This discussion illustrates that school violence manifests itself in different forms and is caused by different factors. Here, it is not so essential to categorise different types of violence in schools because the intention is not to isolate and match causes to possible strategies. The aim is to look at the problem holistically. Henry (2009) also 
argues for a holistic approach, criticising those who look at violence in fragmented ways which, in his view, is a narrow micro-analytical framing of the issue because of failure to consider the multiple causal components of the problem. Whilst not being prescriptive, Bickmore (2011: 651) contends that effective remedies to the problem must be multi-faceted, implemented thoroughly, and should include sustained professional development support for teachers.

This article departs from the premise that school violence is a broad phenomenon with multiple manifest forms. To categorise it into different types will not necessarily add much value in the search for effective remedies. What is crucial in the South African context is to identify systemic loopholes that make schools vulnerable. The question to address is: what breeds school violence and how can it be neutralised in order to create safe and secure schools? This puts under scrutiny the organisation, governance, and management of schools and the effectiveness thereof in combating school violence. It is believed that creating opportunities for school communities to reflect on the problem and determine solutions on their own will stimulate appropriate action to change the situation.

\section{Theoretical Perspectives}

Critical theory underpins this study. This theory originated from Karl Marx but was advanced through the work of Adorno, Habermas and others at Frankfurt in 1923 (Babbie and Mouton, 2012; Held, 1983; Nel, 1995; De Vos et al, 2010; Corradetti, 2014). Babbie and Mouton (2012) argue that the single most distinctive feature of the critical meta-theory is its insistence on science becoming an emancipatory and transformative force in society. They posit that critical theory provides a framework for approaching research as a change-oriented form of engagement that seeks not just to study and understand society but rather to critique and change society. Nel (1995:127) agrees, stating that critical theory "strives for the emancipation of the individual: to enable him or her to shake off these bonds".

McGregor (2003) maintains that, as a theoretical framework, critical emancipatory research (CER) advances "the agenda for equity in all its forms, advocating for social justice, peace, freedom and hope" (in Mahlomaholo, 2009: 226). Goldfarb and Grinberg (2002) define social justice as the exercise of altering the institutional and organisational arrangements by "actively engaging in reclaiming, appropriating, sustaining, and advancing inherent human rights of equity, equality and fairness in social, economic, educational and personal dimensions" (in Theoharis, 2007: 223). Social justice also refers to 'parity of participation', where impediments to equal participation in education are subverted. The underpinning principles include care, recognition of individual rights, respect, redress and fairness (Hlalele, 2014; Tickly, 2010; Fraser, 2008; Gerwitz, 1998).

The legislative framework discussed earlier encapsulates these principles. In whatever form violence manifests itself, it remains totally oppressive, unjust and unfair. Its perpetuation violates basic human rights in society. Broadly speaking, CER argues for generation of knowledge to create awareness about the oppressive and alienating factors that, in this case would sustain violent behaviours in schools. Communities should understand the causes and nature of violence in the schools. This knowledge would transformation their consciousness, ultimately driving them to action for their emancipation. It appears that to-date there is insufficient capacity among school communities to embark decisively on action to combat violence. To successfully confront the problem of violence in schools requires engaging communities fully in all anti-violence programmes.

Community members can no longer be spectators when violence has become such a serious threat to the lives of so many. Parents get directly affected when their children drop out of school as a consequence of violence. Thus, the critical theory emphasises that through self-conscious mobilisation, the community becomes able to assert itself and become stimulated to initiate action to change their circumstances. As Rahman (1993:81) argued, this is about the "stimulation of self-reflected critical awareness on the part of the oppressed people of their social reality and of their ability to transform it by their conscious action" (in Babbie and Mouton). According to these authors, this was first highlighted by Habermas in 1972 when arguing that there is an interest in the human capacity to be self-reflective and self-determining and to act rationally having acquired knowledge which enhances autonomy and responsibility. Therefore, for the communities to be actively engaged, they must be empowered and should be bold and initiate innovations to solve the problem of violence.

This is as much about the emancipatory objective that underpins this theoretical framework as it is about the democratic principles espoused in the legislation. All community members, regardless of position or status, must think free and critically about violence and must be equally empowered to take action against violence. For example, the SGB must feel empowered to engage the principal and SMT in a critique of the current anti-violence interventions and demand to understand the role they should play. Similarly, learners must be vocal about issues of violence that violate their right to safety at school. Parents must demand reasons for abuse of their children and principals must be able to account fully about the state of affairs. It is through this critical engagement that alternative strategies can be debated thereby 
entrenching the democratic principle of participatory decision-making. This will build the much needed team spirit, enhance buy-in and facilitate collaborative action in addressing the problem. Critical theory expects role-players to be activists, focusing on changing their world and making it better.

Based on this, emphasis should be on action upon reflection. Opportunities should exist for communities to criticise whilst empowered to take corrective action. District officials responsible for promoting safety in schools must ensure that all structures are meaningfully engaged by exposing them to capacity building programmes that impact positively on school effectiveness. To be liberated from the scourge of violence, schools need a good vision, adequate resources and continuous support to help them become better self-managing entities, capable of self-renewal.

The problem of violence is dynamic. Perpetrators are not deterred by different measures that are put in place. They are always a step ahead in finding ways to subvert any preventative measures. Schools need to build own capacity to counter violence in its different forms. Failure to do this will trap even the most innovative interventions in the quagmire of inefficiency and ineffectiveness that characterise most schools affected by violence. Therefore, action and reflection must blend to provide a turnkey to change. It is the school communities themselves who must change the situation and liberate their schools from the shackles of violence. What is required is to think critically and act radically to find sustainable solutions. CER situates violence within the organisational contexts which communities must understand in order to act appropriately. In light of this, the article explores the problem of violence in schools by drawing from the views and perceptions of a range of education stakeholders, following the participatory action research approach.

\section{Design and Methodological Approach}

Participatory Action Research (PAR) endorses closeness between the researcher and the researched. According to Babbie and Mouton (2012), PAR emphasises the fundamental importance of experiential knowing and it articulates three broad ways of knowing, namely, thinking, feeling and acting. Although this article reports only on the exploratory phase of the community engagement project in Mpumalanga and KwaZulu-Natal, the long-term goal is on empowering school communities to take actions that will transform their environment.

PAR creates a democratic platform that engages stakeholders actively in finding solutions to their problems since research findings are fed back into the environment from which they were generated. The study explores the perceptions and experiences of school communities, categorised as school management teams (SMTs), school governing bodies (SGBs), representative councils of learners (RCLs), parents, education administrators and social partners regarding the nature and prevalence of violence in schools whilst simultaneously seeking to identify more effective ways of countering the problem. The intention is to illuminate the phenomenon by providing a contextualised in-depth description of the problem whilst deepening its understanding. Research, thus becomes a tool for action to bring about solutions to the problem of violence in schools. Babbie and Mouton (2012: 58) maintain that in PAR, numerous encounters between the researcher and participants are required as research should be seen as a mutual activity that involves the beneficiaries in the analysis of their own reality.

\subsection{Sample}

Purposive sampling was done. Provincial Departments of Education selected districts and schools where violence was most prevalent. Departmental officials responsible for school safety programmes were identified, along with circuit managers responsible who support management and governance functions in the selected schools. Included also were district officials responsible for curriculum and teacher development programmes. Representatives were identified from the SGBs, RCLs, SMTs, and educators in the participating schools. Members of the South African Police Service also participated. Altogether, a sample of 698 participants was realised.

\subsection{Focus groups}

Fieldwork involved two components. Firstly, planning meetings were held with officials to determine the scope and focus of the project. Secondly, a series of in-depth focus group discussions using structured schedules of open-ended questions were conducted. Meaning deducing exercises from narratives and scenarios were done. A senior researcher from UNISA, supported by two emerging researchers facilitated discussions. Under the broad theme of effective organisation and management of schools, discussions covered topics such as education goals, indicators of, barriers to and strategies for schools effectiveness as well as teacher professionalism. Alternatives to corporal punishment and strategies to reduce violence featured in the discussions. The report entitled 'The Dynamics of Violence in Schools in 
South Africa (Mncube and Harber, 2012) provided the context. With the consent of the participants and where feasible, discussions were recorded electronically, whilst detailed notes were captured by the author throughout the process.

\subsection{Data analysis}

Data consisted of transcriptions and notes taken during focus group discussions and from side interviews with selected participants. For purposes of this article, only data from the detailed notes taken by the author have been analysed. After identifying and eliminating redundancies and duplications, data was categorised into key themes that are relevant to the focus of the article. A review of government policies, strategies and research literature on studies of violence in schools was conducted to provide additional data and new insights not covered in the discussions. Given the small size of the study (two provinces), the data from the group discussions were analysed manually in terms of emergent themes as presented below.

\section{Findings and Discussion}

In pursuit of democracy, schools operate through established structures and committees that require effective coordination to maximise their impact. The South African Schools Act (Act 84, 1996) provides for the establishment of school governing bodies (SGBs), school management teams (SMTs) and representative councils of learners (RCLs). It is in this context that Part One of the interview schedule posed questions that relate to the theme: "Effective school organisation and management" while Part Two covered the theme: "Teacher professionalism". The aim is to understand the interplay between these two issues and the prevalence of violence in schools. The notion of the 'duty of care' as a responsibility entrusted upon all educators to ensure learner safety is central in the discussion. Findings on school organisation and management are presented first.

\subsection{Effective school organisation and management}

Generally, organisations establish structures to enhance their effectiveness. An organisation is an institutional framework within which authorised activities are directed and coordinated towards the achievement of specific goals. All organisations have a hierarchy of authority and responsibility. In schools, principals top the hierarchy. They are assisted by the SMTs in carrying out their professional responsibilities. To promote democratic participation, the SGBs should actively participate in formulating school policies. By virtue of their position, principals are accountable for policy implementation and all that operations, including learner protection. The SGBs, SMTs and RCLs should collaborate when carrying out their respective duties. An SMT member commented:

"It is non-negotiable for parents to be involved in fighting violence. The question is how to bring them into the school because without them, we will not succeed".

An SGB member agreed: "We want more parents to be involved in the schools. It is not enough to say the SGB will deal with the problem. Parents
must take an active part in what goes on in the school."

Another member said:

"Right now parents do not get involved. They just wait for invitation. Some do not go to meetings even when invited. There is no ownership".

It is essentially the responsibility of the principal to mobilise all stakeholders into a coherent unit for the smooth functioning of the school. However, these comments suggest that structures are not well-coordinated and could even be dysfunctional. Parents claimed they did not always feel welcome to the school and did not feel comfortable discussing with teachers because some of them were very "hostile". Teachers said they did not always trust SGB members as they felt that they were "spying on them".

A common view was that there is a lack of understanding and no separation of roles and responsibilities between the principals and the SGBs. As a result, tensions always develop. Other participants stressed that healthy working relations between SMTs, SGBs and the teacher unions are necessary to improve school functionality. As one SGB 
member claimed:

"You know it is worse when the principal is an active union member. If the principal is a SADTU member it is not easy to work with the school. Who suffers in the end? It is learners".

To elaborate on the negative consequences of disharmonious relationships, one district official said:

"Look, it is a requirement that each school should have a school safety and security committee (SSSC), to draw up a school safety policy and develop action plans. Its members should come from all the structures. Because of tensions, such committees are dysfunctional".

One participant argued that committees were ineffective due to lack of leadership. Through a protocol agreement signed with the Department of Education in 2000, members of the South African Police Service (SAPS) are expected to provide leadership in anti-violence interventions. The Community Policing Forums (CPFs) are also expected to be visible to create a safe school environment. SAPS members are expected to adopt schools that are at risk and work closely with them over an extended period of time. However, most of these interventions are not implemented in many schools. One participant confirmed this:

"We want to review our safety policy and we want to have safety committees that are trained and functional, not fighting among themselves. The principal must talk to the Department about this".

One teacher felt that the district officials should be liaising with stakeholders, mobilising them to participate in the committees. Although district offices appoint officials to support school safety programmes, participants indicated that district office support is weak. They said circuit managers are not actively involved, yet they should be monitoring the operations of these committees. Participants believed that district officials must "do campaigns to raise awareness about violence" and help "deal with those educators who destroy the future of our girls". If districts do not help, "this problem will never be solved". Some SMT members decried the lack of educational psychologists or counselling facilities in the schools. They cited provinces like the Western Cape and Gauteng where school social workers were being recruited to support victims of violence. Participants thought school nurses were also required to advise learners who fall pregnant or contract STDs. "This cannot be the responsibility of teachers", said one participant.

Lack of "ownership of schools" was cited as an area to be addressed. Participants suggested that schools should partner with the business owners who could adopt schools and lend financial support, for example to improve the physical environment of the schools. An SGB member argued:

"Business owners must plough back to the community through school support projects or community programmes. Schools need fencing, alarm systems, security gates and many materials that shops can donate to make schools safer. The principals must go out there and talk to them and fund-raise also".

In KZN, the role of the traditional leaders was emphasised. One parent stated:

"Here, if the principal does not get the chiefs involved, he will not succeed in stopping violence against children. The chiefs know the troublesome people who go to schools to start problems and harass learners".

Participants also indicated that the ward councillors were an important stakeholder that schools did not often involve in their affairs, yet they could help with resources that schools need. Some believed that councillors could initiate community projects such as protection of learners travelling by public transport, fencing of schools using community members or providing volunteers as security guards in schools. Participants stressed the role of the principal in making sure that harmonious relations were maintained among all stakeholders. This would enhance mandatory parental involvement beyond the superficial interaction during SGB meetings.

An SGB member felt they should be proactive regarding misconduct. One parent suggested the establishment of a stakeholder representative committee to handle cases of sexual abuse of learners. Parents strongly felt that teachers deliberately fail to comply with the Code of Professional Ethics and offending teachers are not subjected to the prescribed disciplinary processes or procedures are not fully implemented. One member said:

"In fact teachers escape punishment because they are favourites of principals or SGB chairperson. Schools should work together with parents on this". 
Learners also voiced their dissatisfaction with management. A learner representative on the SGB said:

"We feel marginalised. We are just given small tasks and we are not involved in decision-making. How can we inform SGB members about violence happening in the school when we do not have a voice? We are always seen as the cause of violence but when it comes to sexual abuse, teachers are doing bad things to girls ... sometimes to boys also but nobody says anything".

Another student added:

"The SGB is not communicating with the SRC - not consulting learner leaders. We are undermined when we give input". Clearly, students want a more democratic leadership where every voice is heard. This signals a need for principals to create a positive school ethos and encourage a more participatory decision-making process. To facilitate this, schools, with the assistance of the departmental officials, could launch sexual harassment awareness campaigns and organise anti-harassment forums where learners could do poster competitions, debate issues and share knowledge about sexual harassment other forms of violence.

\section{A parent advised:}

"Schools must be the starting point to address issues of violence in society. Principals must identify "allies" and involve these as partners so that they become the first line of security guards".

One also said:

"Principals must attend to basic security measures such as ensuring that school gates are locked and visitors to the school are properly identified and their particulars recorded in terms of the prescribed guidelines ... Parental involvement must be 'managed' and not 'controlled' ... and SGB members must be elected democratically and not appointed because of influence of principals or district officials".

Undoubtedly, the perceptions of stakeholders regarding the efficacy of school organisation and management practices are largely negative. The kind of leadership that principals are providing seems to be below expectation. In fact, many alluded to the fact that some principals are not fit to lead or manage schools because they were not appointed on merit but on the basis of their active involvement in teacher unionism. In view of this, some participants felt that principals were generally failing in their professional "duty of care" to ensure learners are safe when under their guardianship.

\subsection{Teacher professionalism}

The professional conduct of educators received much criticism from the participants. The term 'educator' is used here to cover all teachers, including principals and the clerical staff in schools. Educators were seen to be failing to abide by the Code of Professional Ethics and lack professional integrity, self-respect and self-discipline. As such they are not good role-models. When probed on this, one respondent said:

"Teachers were not always punctual and were not duty-conscious ... they waste too much time in meetings or memorial services instead of teaching ... teacher unionism is exaggerated". The behaviour of teachers must bring credit to the profession. The teacher must be exemplary, well-behaved and avoid hostility, not come to school drunk ..."

Participants criticised educators for not complying with policies and for disregarding authority. One SMT member pointed out that "teachers must stick to their code of conduct and do everything according to the law and must protect learners instead of abusing them".

The apparent lack of will among authorities to act against educators who fail to comply with the Code of Professional Ethics was raised strongly. An SMT member remarked:

"The Department will promise investigations and more often, there will be no follow up or publication of results of those investigations to send a message to other perpetrators of violence".

From the discussions, it emerged that some educators failed to act on reported incidents of violence. Such negligence often led to the escalation of violence. Principals sometimes do not report cases of sexual harassment of learners to the South African Council of Educators (SACE) or to initiate disciplinary proceedings against offending 
teachers as required.

A common tendency among some male teachers is to propose girls for sex. A few of these educators will pay parents for damages if girls fall pregnant, but many would deny responsibility, leaving girls traumatised and depressed. Participants voiced anger that such acts of misconduct often go without punishment. One official argued:

"Measures instituted by SACE are often weak and some educators end up not in the register of sex offenders. Sexual relationships are common between young girls and older men usually for monetary and other material benefits. Sugar daddies give them airtime, clothes ... it happens sometimes with the knowledge of the parents... Learners also do it for marks ...this is a problem"

Those learners unwilling to be involved face a double-edged sword. They get unduly punished or their harassment by the educator is prolonged. This translates to abuse of power by virtue of the teacher's position and authority. Learners felt they were not treated with respect and dignity. One student commented that derogatory personal comments and name-calling by educators is more hurtful than corporal punishment as it generates low self-esteem. Students pointed out that many of these incidents go unreported because learners fear victimisation, humiliation, and punishment. Other teachers go to an extent of threatening to fail students who refuse sexual advances.

Reports of continued use of corporal punishment emerged despite it being prohibited by law. This generated a heated discussion with officials cautioning about possibilities of educators being charged for criminal offences. A member said teachers are "expected to respect the law and embrace the constitutional values so that there is less conflict and better discipline" in schools. It was revealed that learners sometimes retaliate when teachers abuse them. A district official observed:

\begin{abstract}
"Teachers need to be more sensitive ... we want to create a child friendly environment where learners feel protected ... right now teachers are disrespectful and reckless, they are aggressive to learners. Some still use corporal punishment. Older learners fight back when provoked. I just wish serious steps can be taken to punish such behaviour".
\end{abstract}

Another official said:

"We want to see human rights based school environments. All teachers must read the Implementation Guidelines for Safe Schools and workshop them. The issue is about creating safe, protective and caring schools and teachers cannot behave contrary to this".

Clearly, the views of participants show the depth of the problem and how it affects the functionality of schools. It would appear that a remedy can only be possible if the government is willing to capacitate schools and place parents at the centre of intervention strategies. The installation of metal detectors, visible policing and employment of security guards, search and seizures, increased surveillance and improvement of physical infrastructure in schools on their own will never adequately change, prevent or reduce violent behaviours. From a social justice perspective, schools do not need retributive policies but policies and strategies that are peace-making and restorative in nature. A much more aware community may be able to transcend the problem by taking appropriate actions to curb violence.

\title{
7. Conclusion
}

The above findings confirm the need to step up safety in schools. Despite the abundance of enabling legislation, the problem is persistent. Failure to reduce violence seems to be linked to a fragmented approach with piecemeal changes to certain aspects of school practices that are unlikely to bring about the desired impact. Strategies are reactive to incidents that have already happened instead of proactively addressing the problem at its source. There must be increased monitoring and supervision to enhance accountability.

It appears that participants are advocating for a systemic, collaborative approach that involves all categories of school communities as the best strategy to tackle the problem. It would seem that only when the whole school community is mobilised to develop a common understanding of the importance of their participation will appropriate actions be taken towards the achievement of the goal of a safe and secure school environment. For this approach to be effective it needs to happen within a framework of a robust policy that is negotiated and owned by all stakeholders. This must be backed up by interventions that put the empowerment of role-players at the centre. The main conclusion is that violence in schools needs to be subverted through implementation of most potent strategies that meaningfully engage school communities. 


\section{Acknowledgement}

I wish to appreciate the opportunity granted by Prof VS Mncube, for me to participate in the community engagement project on school violence in Mpumalanga and in KwaZulu-Natal. Prof. Mncube is the Chair of the Department of Educational Leadership and Management at UNISA and the project sponsor.

\section{References}

Adams, A. T. (2000). The Status of School Discipline and Violence. The Annals of the American Academy of Political and Social Science. Vol. 567 (1), 140-156.

Babbie, E. \& Mouton, J. (2012). The practice of social research. (14th impression). Cape Town, Oxford University Press.

Bickmore, K. (2011). Policies and Programming for Safer Schools: Are "Anti-bullying Approaches Impeding Education for Peacebuilding? Educational Policy, Vol. 25(4), 648-687.

Corradetti, C. (2011). The Frankfurt School and Critical Theory. Internet Encyclopedia of Philosophy. Available at: www.iep.utm.edu/frankfur/. Sourced on 3/9/2014.

De Vos, A.S., Strydom, H., Fouche', C.B. and Delport, C.S.L. (2011). Research at Grass Roots. $4^{\text {th }}$ Edition. Van Schaik, Pretoria.

De Wet, C. (2007). Educators' perceptions and observations of learner-on-learner violence and violence related behaviour. Africa Education Review. Vol. 4 (2), 75-93

Dunne, M., Humphreys, S. and Leach, F. (2006). Gender violence in schools in the developing world. Gender and Education, Vol.18 (1), 75-98.

Education Labour Relations Council. (2000). A Policy Handbook. Government Printers, Pretoria

Goldfarb, K. P. \& Grinberg, J. (2002). Leadership for social justice: Authentic participation in the case of a community center in Caracas, Venezuela. Journal of School Leadership, Vol. 12, pp157-173.

Government Gazette, Notice 20844. (2000). Norms and Standards for Educators. Government Printers, Pretoria.

Government Gazette, Notice 1040. (2001). Regulations for Safety Measures at Public Schools. Government Printers, Pretoria.

Government Gazette, Notice 1589 (2002). Regulations to Prohibit Initiation Practices in Schools. Government Printers, Pretoria.

Grant, C., Jasson, A. and Lawrence, G. (2010). Resilient KwaZulu-Natal schools: An ethics of care. Southern African Review of Education. Vol. 16 (2), 81-99

Henry, S. (2009). School Violence beyond Columbine: A Complex Problem in Need of an Interdisciplinary Analysis. American Behavioural Scientist. Vol. 52 (9), 1246-1265.

Halele, D. (2014). Rural Education in South Africa: Concepts and Practices. Mediterranean Journal of Social Sciences, Vol. 5 (4), 463470.

Hyman, I. A. and Perone, D. C. (1998). The Other Side of School Violence: Educator Policies and Practices that may contribute to student misbehaviour. Journal of School Psychology. Vol. 36 (1), 7-27.

Liang, H., Flisher, A. J. and Lombard, C. J. (2007). Bullying, violence, and risk behaviour in South African School students. Child Abuse and Neglect, Vol. 31, 161-171.

Mahlomaholo, S. (2009). Critical emancipatory research and academic identity. Africa Education Review. Vol. 6 (2), 224-237

Mestry, R., Moloi, K.C. and Mahomed, A. N. (2007). Perspectives on a zero-tolerance approach to discipline: towards maintaining a nurturing and secure school environment. Africa Education Review. Vol. 4 (2), 94-113

Mncube, V. and Harber, C. (2012). The Dynamics of Violence in South African Schools: Report. University of South Africa.

Mncube, V. and Mafora, P. (2013). School Governing Bodies in Strengthening Democracy and Social Justice: Parents as Partners? The Anthropologist. Vol. 15 (1), 13-23.

Naidu, A., Joubert, R., Mestry, R., Mosoge, J., Ngcobo, T. (2013). Education Management and Leadership: A South African perspective. Cape Town, Oxford University Press.

Nel, B. F. (1995). Critical Theory: Origins, Central Concepts and Education (123-137). In Higgs, P. (ed.), (1995). Metatheories in Philosophy of Education. Heinemann, Johannesburg.

Prinsloo,S. (2006). Sexual harassment and violence in South African school. South African Journal of Education. Vol. 26(2), 305-318.

Republic of South Africa. (1996a). Constitution of the Republic of South Africa, Act No.108 of 1996. Government Printers, Pretoria.

Republic of South Africa. (1996b). South African Schools Act, Act No.84 of 1996. Government Printer, Pretoria.

Republic of South Africa. (1998). Employment of Educators Act, Act No.76 of 1998. Government Printer, Pretoria.

Republic of South Africa. (2000). South African Council for Educators Act, Act No.31 of 2000. Government Printer, Pretoria.

Theoharis, G. (2007). Social Justice Educational Leaders and Resistance: Toward a Theory of Social Justice Leadership. Educational Administration Quarterly, Vol. 43 (2), 221-258. 